\title{
JUCER \\ Software Development to Reduce Misconceptions Using Conceptual Change Text Strategy on Chemical Bonding
}

\author{
Sovranita Ramadhani Setaiwan Putria, Sukarmin ${ }^{a},{ }^{*}$ \\ ${ }^{a}$ Chemistry Department, Faculty of Mathematics and Science, State University of Surabaya, Surabaya, \\ Indonesia \\ ${ }^{*}$ Corresponding author: sukarmin@unesa.ac.id
}

\begin{abstract}
The aims of this research is to determine the feasibility of software to reduce students misconception using conceptual change text strategy on chemical bonding matter. This research is using Research \& Development (R\&D) design with 1st grade MAN Sidoarjo's students as a subject. The instrument used are student response, student activity observation, and pretest-posttest sheet. Software developed using PHP (Hypertext Preprocessor) programming language. The result analyzed using descriptive quantitative method that can be concluded as (1) Software is valid showed by content validity average percentage is $88,57 \%$ with very valid criteria and construct validity average percentage is $88,89 \%$ with very valid criteria (2) The practicity of software got $87,41 \%$ with very practice criteria (3) Software effective in detect and reduce misconception that showed by percentage the average shift of conception from misconception to know the concept is $83.53 \%$.
\end{abstract}

Keywords: software, misconception, conceptual change text, chemical bonding

\section{INTRODUCTION}

Chemistry is a branch of science that contains facts, concepts, laws, theories. The concepts in chemistry are related to one another and most of them are abstract. For that reason, while understanding one concept, it will affect other concepts. The learning becomes complicated because student must be truly understood one concept before continuing to other concepts [1]. Concept is a collection of facts, objects, events, and others that all have the same characteristics or attributes. One can observe the characteristics or attributes of each of these concepts to be able to distinguish between one concept with another [2]. The conceptual structure that is sequential and interrelated with one another as in chemistry becomes a supporting factor for frequent misconceptions. Misconceptions can occur because the concepts mastered by students are still incomplete and simple or different, the inability of students to distinguish the characteristics of concepts, students who do not understood the previous concepts, the language used by students, learning resources used by students, and concept's example [3].

Chemical Bonding is one of chemical concepts that often occur misconceptions, as in the results of pre-research in MAN Sidoarjo found that $48.68 \%$ of students experience ionic bond misconceptions and $73.68 \%$ experience covalent bond misconceptions. Misconceptions that occur in these students must be reduced so as not to affect the next concept. To reduce misconceptions, Conceptual Change Text strategy is used, which is a learning strategy to fundamentally change existing concepts or even change them into conceptual frameworks that can be used to solve problems, explain phenomena, and be useful in everyday life for students [4].

There are four stages in this strategy, namely 1) showing students' conceptions, 2) creating conceptual conflicts, 3) equilibration processes, 4) reconstructing concepts. Conceptual conflict stages in conceptual change text can be used to reduce students' misconceptions. This conflict results in schemes or concepts that are owned by students become unbalanced (disequilibrium). This condition of disequilibrium when students have doubts about their concepts, so students can reconstruct the wrong concepts so that students can understand new concepts that are good and right [5].

The Four-tier diagnostic test method is used to detect misconceptions consisting of four levels. This method is the development of a three-tier diagnostic test. The development contained in the addition of questions about students' beliefs in choosing answers and reasons. The advantage of the four-tier test is that teachers can diagnose misconceptions experienced by students more deeply, differentiate the level 
of confidence in the answers and confidence level of the reasons chosen by students so that they can dig deeper about the power of understanding the concept of students [6].

Multimedia is needed as a supporting factor in detecting and reducing misconceptions. Because with the help of the media, it is expected to get more effective and efficient results compared to the interview test or written test to analyze and process data [7]. In the stage of reducing misconceptions, the media can also connect abstract concepts with real life. Therefore the media is suitable to be used to convey chemical concepts because the microscopic level of the field of chemical studies causes chemistry to be considered an abstract science so that the appearance of interactive multimedia can represent abstract concepts[8].

So, it can be concluded that multimedia with methods and strategies to detect and reduce misconceptions is needed in more effective and efficient ways of working. Therefore, the development of research entitled "Development of Software to Reduce Students' Misconceptions with Conceptual Change Text Strategies in Chemical Bonding Materials". And based on the background that has been stated, then a general problem can be formulated namely "How is the feasibility of the software to reduce students' misconceptions with the conceptual change text strategy on chemical bonding matter based on validity, practically, and effectivity of the software?"

\section{METHOD}

The research design used was a research and development method (Research \& Development) written by Sugiyono (2016). The R\&D method is a research method used to develop and test a product. There are 10 development steps in this method, namely (1) potential and problems, (2) data collection, (3) product design, (4) design validation, (5) design revision, (6) product trial, (7) product revisions, (8) trial use, (9) product revisions, and (10) mass production. This study aims to test the feasibility so the R\&D method is only until the product trial step. Following is the flow of this research.

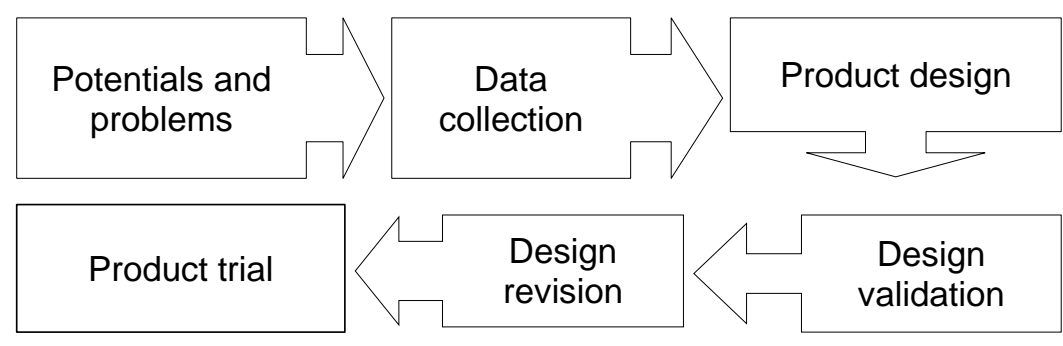

FIGURE 1. Method Steps Research and Development (R\&D) [9]

Analysis of the conception shift is used to determine misconceptions that occur in students after using software by using a test method. This test contains pretest and posttest questions with the four-tier test method. In this four-tier test method, students must first choose answers from multiple choice questions. Second, about students' confidence in choosing the first level answers. Third, the reason students answer the first level questions. Fourth, about students' confidence in choosing reasons at the third level. In this four-tier test method there is a classification of students towards the category of concept understanding shown in Table 1.

TABLE 1. Four-tier combination[10]

\begin{tabular}{ccccc}
\hline Answer & $\begin{array}{c}\text { Confiden } \\
\text { ce level }\end{array}$ & Reason & $\begin{array}{c}\text { Confiden } \\
\text { ce level }\end{array}$ & Criteria \\
\hline True & Sure & True & Sure & Know Concept \\
True & Not & True & Not & \\
True & Sure & True & Not & \\
True & Not & True & Sure & Don't Know \\
True & Not & False & Not & Concept (DKC) \\
False & Not & True & Not & \\
False & Not & False & Not & \\
True & Sure & False & Not &
\end{tabular}




\begin{tabular}{ccccc}
\hline Answer & $\begin{array}{c}\text { Confiden } \\
\text { ce level }\end{array}$ & Reason & $\begin{array}{c}\text { Confiden } \\
\text { ce level }\end{array}$ & Criteria \\
\hline False & Not & True & Sure & (M1) \\
True & Not & False & Sure & (M2) \\
True & Sure & False & Sure & (M3) \\
False & Sure & True & Not & (M4) \\
False & Sure & True & Sure & (M5) \\
False & Sure & False & Not & (M6) \\
False & Not & False & Sure & (M7) \\
False & Sure & False & Sure & \\
\hline
\end{tabular}

The analysis of data resulting from the shift in misconception can be seen in students who have experienced a change in the understanding of the concept that was originally a misconception $(\mathrm{M})$ to know the concept $(\mathrm{KC})$. How to identify it is by looking at the results of the shift obtained from students who work on pretest and posttest questions in software. The formula used to analyze the results of a misconception shift is:

$\mathrm{P}(\%)=\frac{\Sigma \mathrm{M}-\mathrm{KC}}{\Sigma \mathrm{M} \text { initial }} \times 100 \%$

Desc:

$\mathrm{P}(\%)=$ percentage misconceptions shift.

$\Sigma \mathrm{M}-\mathrm{KC}=$ the number of misconceptions shifts into know concepts

$\Sigma \mathrm{M}$ initial $=$ number of students' initial misconceptions

\section{RESULTS AND DISCUSSION}

The product trial was conducted by 15 students on 1st grade in MAN Sidoarjo. The subjects chosen by conducting a written test on all students in the class to take 15 samples of students who conducted misconceptions on chemical bonding. The data obtained are the results of students 'responses obtained from students' assessments of the software, the results of observations of students 'activities obtained from observations of students, and the results of students' conception shifts obtained from the matter of pretest and posttest in the software based on the method Four Tier Test. Based on previous studies, it was found that the use of conceptual change text strategies in the classroom would be effective in reducing misconceptions[12]. In addition, the study also states that the use of software can be used to reduce students' misconceptions on chemical bonding material which is still often the case[13].

\section{Feasibility Analysis Based on Validity}

\section{Content Validity}

Validation data analysis is performed by calculating the number of scores based on a Likert scale. An assessment of validation can be obtained from a Likert scale based on Table 2.

TABLE 2. Likert Scale

\begin{tabular}{lc}
\hline \multicolumn{1}{c}{ Category } & Scale \\
\hline Very good & 5 \\
Good & 4 \\
Not Bad & 3 \\
Bad & 2 \\
Very Bad & 1 \\
\hline
\end{tabular}

Furthermore, the results of the scale data are calculated using the formula:

$$
\text { Percentage }(\%)=\frac{\text { score obtained }}{\text { max score }} \times 100 \%
$$

The calculation is used to determine the validity of the software interpreted in the score in Table 3. 
TABLE 3. Validity Score Interpretation

\begin{tabular}{cc}
\hline Percentage & Category \\
\hline $0 \%-20 \%$ & Very Lack \\
$21 \%-40 \%$ & Less \\
$41 \%-60 \%$ & Enough \\
$61 \%-80 \%$ & Valid \\
$81 \%-$ & Very valid \\
$100 \%$ &
\end{tabular}

Based on the average percentage of software content validation shows that the range of values obtained from all aspects of content validation is between $80 \%-93.33 \%$ so that an average percentage of $88.57 \%$ is obtained and belongs to the very criteria valid, meaning that the material and CCT contained in the software can be said to be valid and suitable for use by students.

\section{Construct Validation}

Based on the average percentage of software construct validity shows that the range of values obtained from all aspects of construct validation is between $86.67 \%-93.33 \%$ so that an average percentage of $88.89 \%$ is obtained and is included in the very valid criteria which means the use of language, appearance and ease of use of software can be said to be valid or appropriate for students to use.

\section{Feasibility Analysis Based on Student Responses}

Data on the results of students 'responses supported by observations of students' activities showed that an average percentage of $87.41 \%$ was obtained and included in the category of very practical, shown as follows:

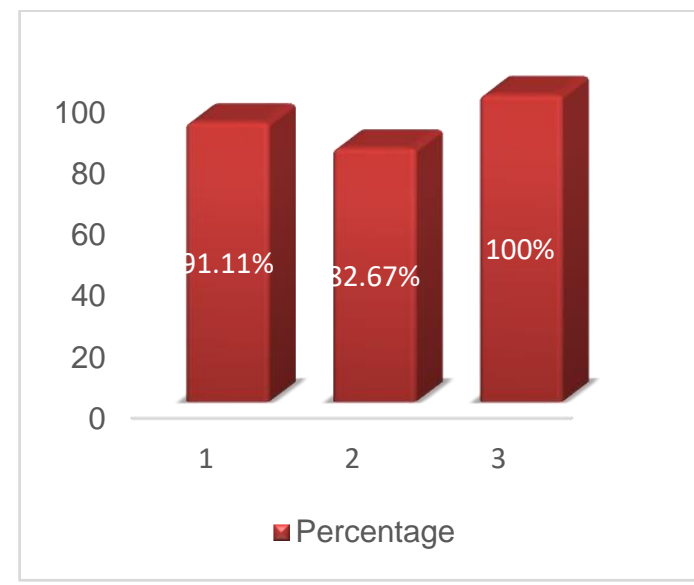

FIGURE 2. Student Responses

The first aspect is according to the feasibility of software's appearence obtained a percentage of $91.11 \%$ and included in the category of very practical. These results indicate that students interested in the appearance of the software. The results of the students 'responses are supported by observations of students' activity that there are no student that leave the room during the trial without reason and the students read carefully every stage in the CCT.

The second aspect is according to the language and the ease of operation of the software obtained a percentage of $82.67 \%$ and included in the category of very practical. These results indicate that most students can understand the language used. However, there are some students who do not understand the language used in software. This is shown in the observation of students' activities that there are some students who ask questions about instructions on how to use and function buttons in the software.

The third aspect is according to the level of student learning motivation by using software gets a percentage of $100 \%$ and belongs to the category of very practical. These results indicate that the software makes student feels more motivated to study chemistry.

Our research participants place instruction and teaching as the number one method to improve learning 
of multistep organic synthesis. This is consistent with research in the field that suggests students should be given ample opportunities and provided with engaging instruction to develop their skills and competencies in solving reaction problems mechanistically [33]. We think that student should move from recall and comprehension into evaluation, analysis and synthesis. The more actively involved in the learning process, the better the students will perform on synthesis problems. One example of active learning is POGIL method for teaching and learning organic chemistry which resulted in greater understanding of content and positively impacted student performance on the standardized ACS organic chemistry exam when compared to traditional lecture format [35].

\section{Feasibility Analysis Based on Student's Conception Shift}

The results of the students conception shift are obtained from output data on software in the form of pretest and posttest results compiled using the four tier test method contained in the software. The following are details of the pretest result by 15 students on chemical bonding material can be seen in Figure 3 and Figure 4.

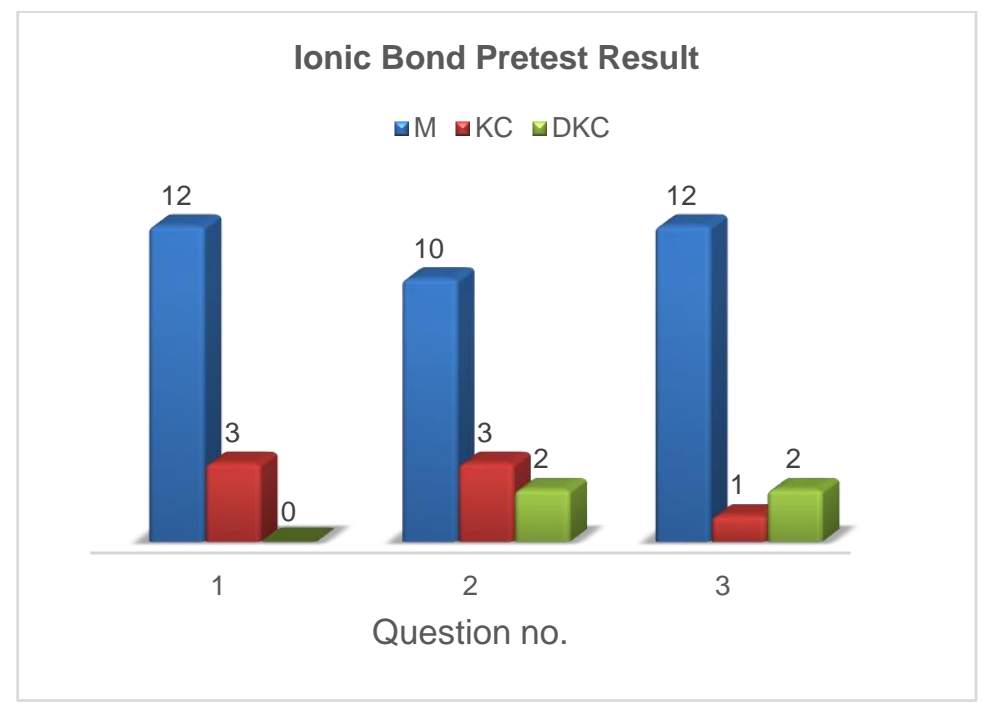

FIGURE 3. Ionic Bond Pretest Result

$\mathrm{M}=$ Misconception

$\mathrm{KC}=$ Know the Concept

$\mathrm{DKC}=$ Do not Know the Concept

Figure 3 shows that in the pretest concept of ion bonding as many as 12 students experienced misconceptions (M), know the concepts (KC) as many as 3 students, and there were no students who experienced did not know the concept (DKC) in question number 1. For questions about number 2 as many as 10 students experienced misconceptions (M), know the concepts (KC) as many as 3 students, and 2 students experienced did not know the concepts (DKC). For question number 3, 12 students experienced misconceptions (M), know the concept (KC) of 1 student, and 2 students did not know the concept (DKC). The details of the results of the pretest showed that $75.56 \%$ of students experienced misconceptions. 


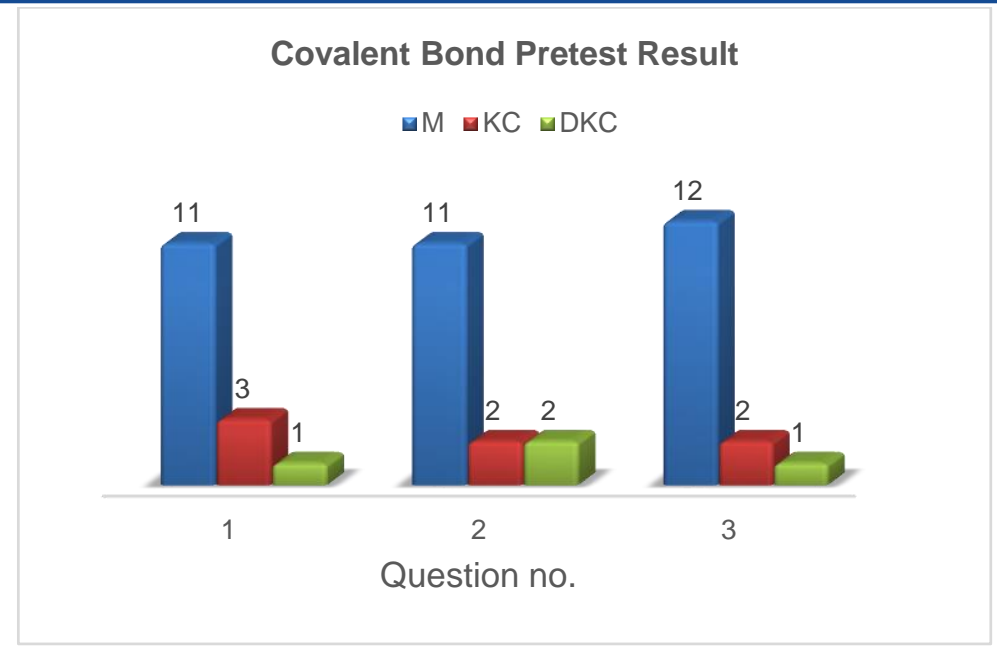

FIGURE 4. Covalent Bond Pretest Result

$M=$ Misconception

$\mathrm{KC}=$ Know the Concept

$\mathrm{DKC}=$ Do not Know the Concept

Figure 4 shows that in the pretest the concept of covalent bonds as many as 11 students experienced misconceptions (M), know the concepts (KC) as many as 3 students, and 1 student didn't know the concepts (DKC) in question number 1. For question number 2 as many as 11 students experience misconceptions (M), know the concepts (KC) as much as 2 students, and 2 students experience didn't know the concepts (DKC). For problem number 3, 12 students experienced misconceptions (M), know the concepts (KC) as many as 2 students, and 1 student didn't know the concepts (DKC). The details of the results of the pretest showed that $75.56 \%$ of students experienced misconceptions.

After student did the Conceptual Change Text strategy on the software, student continue to do posttest. From the pretes-posttest data, can be known the conception shift that occurs. The following are details of the conception shift by 15 students on chemical bonding material can be seen in Table 4 .

TABLE 4. The Conception Shift of Chemical Bond

\begin{tabular}{|c|c|c|c|c|c|c|c|c|c|}
\hline \multirow[t]{2}{*}{ No } & \multirow{2}{*}{$\begin{array}{c}\text { Conception } \\
\text { shift }\end{array}$} & \multicolumn{3}{|c|}{ Ionic Bond } & \multirow[t]{2}{*}{ Total } & \multicolumn{3}{|c|}{ Covalent Bond } & \multirow[t]{2}{*}{ Total } \\
\hline & & 1 & 2 & 3 & & 1 & 2 & 3 & \\
\hline 1 & $\mathrm{M}-\mathrm{KC}$ & 11 & 8 & 10 & 29 & 9 & 8 & 11 & 28 \\
\hline 2 & $M-D K C$ & 1 & 2 & 1 & 4 & 1 & 2 & 0 & 3 \\
\hline 3 & $M-M$ & 0 & 0 & 1 & 1 & 1 & 1 & 1 & 3 \\
\hline 4 & TPK - KC & 0 & 2 & 0 & 2 & 1 & 0 & 0 & 1 \\
\hline 5 & $\mathrm{DKC}-\mathrm{DKC}$ & 0 & 0 & 2 & 2 & 0 & 2 & 1 & 3 \\
\hline 6 & $\mathrm{DKC}-\mathrm{M}$ & 0 & 0 & 0 & 0 & 0 & 0 & 0 & 0 \\
\hline 7 & $K C-K C$ & 3 & 3 & 1 & 7 & 3 & 2 & 2 & 7 \\
\hline
\end{tabular}

The following analysis of the results of students' conception shifts from each concept and each item:

1. Ionic bonds

In the first pretest question, based on data from the students' conception shifts is known that students who experienced a conception shift from misconception to conceptual understanding as many as 11 out of 12 students who were initially misconceptions. So that the percentage of misconceptions shifting into knowing the concept (M - KC) in the first problem of the concept of ionic bonds amounted to $91.67 \%$. In the second problem, known that students who experienced a conception shift from misconception to conceptual understanding as many as 8 out of 10 students who were initially misconceptions. So the percentage of misconceptions shifting to knowing the concept (M-KC) in the second problem of the concept of ionic bond by $80 \%$. In the third problem, known that students who experienced a conception shift from misconception to conceptual understanding as many as 10 out of 12 students who were initially 
misconceptions. So that the percentage of misconceptions shifting into knowing the concepts (M - KC) in the second problem of ionic bonding concepts is $83.33 \%$.

2. Covalent bonds

In the first pretest question, known that students who experienced a conception shift from misconception to conceptual understanding as many as 9 out of 11 students who were initially misconceptions. So that the percentage of misconceptions shifting into knowing the concept (M - KC) in the second problem of covalent bonding concepts is $81.82 \%$. In the second question, as many as 8 out of 11 students who were initially misconceptions. So the percentage of misconceptions shifting to knowing the concept ( $\mathrm{M}-\mathrm{KC}$ ) in the second problem of the concept of covalent bond is $72.73 \%$. In the third problem, it is known that students who experienced a conception shift from misconception to conceptual understanding as many as 11 out of 12 students who were initially misconceptions. So that the percentage of misconceptions shifting into knowing the concepts $(\mathrm{M}-\mathrm{KC})$ in the second problem of covalent bonding concepts is $91.67 \%$.

Data from the percentage of misconception shifts (M) into knowing the concepts (KC) on chemical bonding material showed an average percentage of $83.53 \%$ and included in the very effective category. With details on the concept of ionic bonds by $85 \%$ and the concept of covalent bonds of $82.07 \%$. The data shows that the software can be said to be effective in reducing students' misconceptions on chemical bonding material.

\section{CONCLUSION}

Based on the results of the students' responses, the results of observations of the students' activities, and the results of the students' conception shifts it can be concluded that Software is valid showed by content validity average percentage is $88,57 \%$ with very valid criteria and construct validity average percentage is $88,89 \%$ with very valid criteria; The practicity of software got $87,41 \%$ with very practice criteria; Software effective in detect and reduce misconception that showed by percentage the average shift of conception from misconception to know the concept is $83.53 \%$. So the software is appropriate to be used to detect and reduce misconceptions.

\section{REFERENCES}

1. Fahmi and Y. Irhasyuarna. Journal of Education and Practice. 8 (17) 32-39 (2017).

2. P. Lestari and S. Linuwih. Unnes Physics Education Journal. 3 (2) 62-67 (2014).

3. M. Ibrahim, Konsep, Miskonsepsi, dan Cara Pembelajarannya, (Unesa Press, Surabaya, 2012).

4. N. K. Khoiriyah and Erman. E-Jurnal Pensa. 5 (3) 330-334 (2017).

5. A. Aslan and G. Demircioglu. Procedia Social And Behavioral Sciences. 116 (1) 3115- 3119 (2014).

6. N. Amin, Wiendartun and A. Samsudin. Simposium Nasional Inovasi dan Pembelajaran Sains (SNIPS). 4 (2) 570-574 (2016).

7. Fitria, S. Priatmoko and Kasmui. Jurnal Inovasi Pendidikan Kimia, 10 (1) 1641-1650 (2016).

8. D. Kici. International Journal of New Trends in Art, Sport \& Science Education. 1 (2) 30-40 (2012).

9. Sugiyono, Metode Penelitian Kuantitatif, Kualitatif, dan R\&D, (Alfabeta, Bandung, 2016).

10. Q. Fariyani, A. Rusilowati, Sugianto. Journal of Innovative Science Education. 4 (2) 41-49 (2015).

11. Rahmawan and Sukarmin. Unesa Journal of Chemical Education. 2 (2) 100-107(2013).

12. D. McKenna. Education and Human Development Master's Theses. 5 (2) 521-527(2014).

13. S. Safrida, C. R. Dewi, and A. Abdullah. Jurnal Pencerahan. 11 (1) 39-45(2017).

14. Riduwan, Skala Pengukuran Variabel-Variabel Penelitian, (Alfabeta, Bandung, 2015). 